\title{
PENANAMAN NILAI-NILAI KEISLAMAN MELALUI KEBIJAKAN HOLISTIK INTEGRATIF KEPALA TK AL-FADLILAH SAMBILEGI KIDUL YOGYAKARTA
}

\author{
Remiswal \\ Universitas Islam Negeri Imam Bonjol Padang, Indonesia \\ Email: remiswal@uinib.ac.id
}

\section{Arham Junaidi Firman}

Universitas Islam Negeri Sunan Kalijaga Yogyakarta, Indonesia

Email:arhamif@yahoo.com

\begin{abstract}
The objective of this study is to explore the cultivation of Islamic values through the integrative holistic policy of the principal of TK Al-Fadlilah Yogyakarta in improoving school credibility. This study used field study with qualitative approach and program evaluation method. Technique of data collection of this study are observation, documentation and interviews. This study revealed: First, the form of an integrative holistic policy implemented by the principal of TK Al-Fadlilah that covers the healt sector, nutrition sector, educational stimulation sector, care and protection sector. Secondly, the impact of an integrative holistic policy applied by the principal of TK Al-Fadlilah includes both positive and negative impacts. Thridly, the factors that influence the implementation of an integrative holistic policy from principal of TK Al-Fadlilah policy include supporting factors and inhibiting factors. Further, Islamic values are isntilled to students in TK Al-Fadlilah can be grouped into three main components, namely aqidah, worship and morals.
\end{abstract}

Keywords: Islamic values, integrative holistic policy, TK Al-Fadlilah

\section{A. Pendahuluan}

Pemimpin adalah orang yang melakukan kegiatan dalam usaha mempengaruhi orang lain yang ada di lingkungannya pada situasi tertentu agar orang lain mau bekerja dengan rasa penuh tanggungjawab demi tercapainya tujuan yang telah ditetapkan. Kepala sekolah merupakan pimpinan pada lembaga yang dipimpinnya, maju dan berkembangnya suatu lembaga tersebut merupakan tugas dan tanggung jawab kepala sekolah. ${ }^{1}$

Keberhasilan kepala sekolah dalam pelaksanaan program kebijakan tersebut, diasumsikan sebagai hasil dari kerja keras dan kepiawaian kepala sekolah dalam

${ }^{1}$ Wahjosumidjo, Kepemimpinan Kepala Sekolah (Jakarta: PT Raja Grafindo Persada, 2007), 83 
membuat kebijakan-kebijakan operasional dalam meningkatkan kredibilitas sekolah. Asumsi ini bertolak dari kerangka pikir bahwa kunci keberhasilan pendidikan di sekolah/madrasah pada dasarnya bergantung pada kebijakan kepala sekolah/madrasah dalam meningkatkan kredibilitas sekolah dan di dalam melaksanakan suatu kepemimpinan pendidikan dan cara bertindak. ${ }^{2}$

Keberhasilan itu tentu saja tidak dapat dilepaskan dari keberhasilan kepemimpinan kepala sekolah. Kebijakan kepala sekolah dalam proses meningkatkan kredibilitas sekolah termasuk upaya kepala sekolah untuk mengetahui kemampuan dan perilaku setiap para pengajar yang dipengaruhi tidak hanya oleh ilmu, melainkan keterampilan yang diperoleh selama peserta didik mengalami proses belajar mengajar, motivasi kerja, sikap, latar belakang budaya dan pengaruh lingkungan. Kebijakan kepala sekolah dalam meningkatkan kredibilitas sekolah di TK Al-Fadlilah harus berupaya mengembangkan visi, tujuan, dan sasaran yang ditetapkan sebelumnya.

Proses pencapaian visi, tujuan dan sasaran di TK Al-Fadlilah dapat dilaksanakan jika sekolah memiliki kebijakan utama dalam proses pengembangannya. Kebijakan utamanya yaitu memiliki otoritas yang diperlukan dalam melaksanakan kepemimpinan secara keseluruhan, mampu mengidentifikasi kebutuhan-kebutuhan akan suatu perubahan dan dapat mengontrol sumber daya yang dimiliki untuk mengimplementasikan kebijakannya. Kepala sekolah tidak hanya mampu memprakarsai kebijakan, tetapi juga mampu memberikan dukungan yang diperlukan guru secara individual atau kelompok dalam kegiatan meningkatkan kredibilitas sekolah.

Kebijakan kepala sekolah sangat penting karena di dalamnya terdapat berbagai cara dalam meningkatkan kredibilitas sekolah yang ditanamkan dalam kegiatan belajar mengajar. Bertolak dari pendapat tersebut, terlihat bahwa tuntutan akan pentingnya kebijakan kepala sekolah dalam rangka meningkatkan kredibilitas sekolah didasarkan pada kompetensi, status, tugas, dan fungsi kepala sekolah. ${ }^{3}$

Berdasarkan itu, diharapkan di TK Al-Fadlilah dalam penyelenggaraan kebijakan kepala sekolah sebagai upaya meningkatkan kredibilitas sekolah mampu memfasilitasi siswanya untuk dapat belajar, berlatih secara individual, mengaktualisasikan semua potensi yang dimilikinya melalui penanaman nilai-nilai keislaman dengan metode ilmiah

${ }^{2}$ E. Mulyasa, Menjadi Kepala Sekolah Profesional (Bandung: PT Remaja Rosdakarya, 2007), 216

${ }^{3}$ Hari Suderadjat, Manajemen Peningkatan Mutu Berbasis Sekolah (Bandung: Cipta Cekas Grafika, 2005), 140 
sehingga menjadi lulusan yang unggulan, dan serta dapat meningkatkan prestasi belajar para peserta didiknya. Tanpa motivasi, minat siswa tidak akan muncul sehingga kebutuhan yang mendasar tidak akan terpenuhi, yang dapat menyebabkan perbuatan belajar tidak akan terjadi secara efektif. ${ }^{4}$

Selain itu, berdasarkan hasil pengamatan peneliti melalui observasi empirik di lapangan menunjukkan bahwa salah satu kebijakan yang menarik minat peneliti untuk melaksanakan penelitian di TK Al-Fadlilah adalah diterapkannya program holistik integratif dalam penanaman nilai-nilai keIslaman, seperti melaksanakan shalat dhuha satu kali seminggu di setiap hari Sabtu. Program holistik integratif adalah pengembangan anak usia dini yang dilakukan untuk memenuhi kebutuhan esensial anak yang beragam, meliputi berbagai aspek fisik dan non fisik, termasuk mental, emosional dan sosial. Program holistik integratif sendiri sudah diterapkan di TK Al-Fadlilah sejak tahun 2015.

Usaha penanaman nilai-nilai keIslaman melalui kebijakan holistik program dihadapkan pada berbagai tantangan baik secara internal maupun eksternal. Secara internal, pendidikan di TK Al-Fadlilah dihadapkan pada masalah internal siswa yang secara psikologis masih dalam usia dini. Begitu pula pada aspek pembelajaran lainnya, seperti kurikulum, sistem evaluasi dan kompetensi guru. Secara eksternal, pembelajaran di TK dihadapkan pada masalah tren perkembangan zaman yang sangat susah dikendalikan seperti, etika pergaulan, perkembangan teknologi informasi dan masalah sosial lainnya. ${ }^{5}$

Kemerosotan nilai-nilai moral yang mulai melanda masyarakat saat ini tidak lepas dari ketidakefektifan penanaman nilai-nilai keIslaman, baik di lingkungan pendidikan formal, nonformal maupun pendidikan informal. Terjadinya dekadensi moral berupa berbagai kejahatan pemerkosaan, perampokan dan korupsi, penyalahgunaan kemajuan ilmu pengetahuan teknologi untuk kejahatan seperti kejahatan melalui handphone dan internet. Perubahan perkembangan ilmu pengetahuan dan teknologi (IPTEK) ini dapat menyebabkan peserta didik yang belum mempunyai kesiapan mental dalam menerima

\footnotetext{
${ }^{4}$ Sugeng Listyo Prabowo, Manajemen Pengembangan Mutu Sekolah/Madrasah (Malang: UINMalang Press, 2008), 201

${ }^{5}$ Rini Setyaningsih \& Subiyantoro, "Kebijakan Internalisasi Nilai-nilai Islam dalam Pembentukan Kultur Religius Mahasiswa,” Edukasia: Jurnal Penelitian Pendidikan Islam 12, 1 (2017): 62
} 
perubahan sehingga mengakibatkan perilaku menjadi labil dalam menghadapi kenyataan dan fenomena yang berkembang. ${ }^{6}$

Oleh karena itu, tulisan ini mengungkap lebih dalam seperti apa penanaman nilainilai keIslaman melalui kebijakan holistik integratif kepala TK Al-Fadlilah yang pada tahap akhir diharapkan dapat menghasilkan rekomendasi berupa pengembangan sekolah ke arah yang lebih baik sehingga mampu memberikan kontribusi yang lebih besar dan terarah terhadap generasi bangsa. Berdasarkan deskripsi di atas, maka dapat dirumuskan pokok permasalahan dalam penelitian ini, yaitu bagaimana penanaman nilai-nilai keIslaman melalui kebijakan holistik integratif kepala TK Al-Fadlilah Sambilegi Kidul Yogyakarta dalam meningkatkan kredibilitas sekolah. Mengingat luasnya cakupan rumusan masalah tulisan di atas, maka penulis perlu membatasinya menjadi beberapa batasan, Pertama, profil TK Al-Fadlilah. Kedua, bentuk kebijakan holistik integratif kepala TK Al-Fadlilah. Ketiga, dampak kebijakan holistik integratif kepala TK AlFadlilah. Keempat, faktor yang mempengaruhi program holistik integratif sebagai kebijakan kepemimpinan kepala TK Al-Fadlilah. Kelima, nilai-nilai keislaman yang ditanamkan melalui kebijakan holistik integratif di TK Al-Fadlilah.

\section{B. Metode}

Tulisan ini berasal dari hasil penelitian, di mana jenis penelitian ini adalah penelitian lapangan (field research). ${ }^{7}$ Pendekatan yang digunakan dalam penelitian ini adalah pendekatan kualitatif dengan metode evaluasi program. Pendekatan kualitatif adalah suatu proses penelitian dan pemahaman yang berdasarkan pada metodologi yang menyelidiki suatu fenomena sosial dan masalah manusia. Sedangkan pendekatan evaluasi program adalah suatu proses menyediakan informasi yang dapat dijadikan sebagai pertimbangan untuk menentukan tujuan yang hendak dicapai, desain, implementasi dan dampak untuk membantu membuat keputusan, membantu pertanggungjawaban dan meningkatkan pemahaman terhadap fenomena. ${ }^{8}$

Kegiatan penelitian ini dilangsungkan pada TK Al-Fadlilah Sambilegi Kidul Yogyakarta. Sumber data dalam penelitian ini meliputi: Pertama, sumber data primer

\footnotetext{
${ }^{6}$ Yustiani, "Penanaman Nilai-nilai Karakter Bangsa Melalui Mata Pelajaran Pendidikan Agama Islam di SMA Negeri," Analisa Journal of Social and Religion 22, 01 (2015): 136 2005), 60

${ }^{7}$ Nana Syaodih Sukmadinata, Metode Penelitian Pendidikan (Bandung: Remaja Rosda Karya,

${ }^{8}$ Suharsimi Arikunto, Dasar-dasar Evaluasi Pendidikan (Jakarta: Aneka Cipta, 2009), 11
} 
dalam penelitian ini adalah kepala TK Al-Fadlilah, tenaga pendidik dan kependidikan, sumber data sekunder dalam penelitian ini adalah data dokumentasi, antara lain buku atau naskah yang berkaitan dengan penelitian.

Teknik pengumpulan data yang peneliti gunakan dalam penelitian ini, yaitu observasi, wawancara dan dokumentasi. Analisis data dalam penelitian ini dilakukan dengan reduksi data, display data dan verifikasi data. Sedangkan teknik uji keabsahan data dalam penelitian kualitatif meliputi uji credibility (validitas internal), transferability (validitas eksternal), dependability (reliabilitas) dan confirmability (objektivitas). ${ }^{9}$

\section{Hasil Penelitian dan Pembahasan}

\section{Bentuk Kebijakan Holistik Integratif Kepala TK Al-Fadlilah}

Dalam konteks pendidikan anak usia dini, pendidikan holistik adalah penanganan anak usia dini secara utuh/menyeluruh yang mencakup layanan pendidikan, gizi seimbang, kesehatan, pengasuhan, dan perlindungan, untuk mengoptimalkan semua aspek perkembangan anak. Sedangkan pendidikan integratif/terpadu, adalah penanganan anak usia dini yang dilakukan secara terpadu oleh berbagai pemangku kepentingan di tingkat masyarakat dan pemerintah. ${ }^{10}$

Kebijakan kepala sekolah termasuk kepala TK Al-Fadlilah pada dasarnya adalah proses berfikir sistematis dan analitis untuk mengembangkan program-program kebijakan dalam rangka pencapaian tujuan instutisional. Berdasarkan hal itu, berikut adalah berbagai bentuk kebijakan program holistik integratif yang diterapkan oleh kepala TK Al-Fadlilah.

a. Kesehatan

Program holistik integratif di bidang kesehatan meliputi kegiatan pemeriksaan kesehatan umum, pemeriksaan kesehatan gigi, pemeriksaan DDTK dan rujukan ke Puskesmas. Kegiatan pemeriksaan kesehatan umum dan kesehatan gigi dilakukan oleh petugas medis dengan pembiayaan dari Puskesmas Depok I. Sementara itu, pemeriksaan DDTK (setiap bulan) dan rujukan ke Puskesmas (setelah pemeriksaan kesehatan dari Puskesmas) yang dilakukan dan dibiayai oleh guru kelas dan orang tua. Berdasarkan hasil

\footnotetext{
${ }^{9}$ Sugiyono, Metode Penelitian Pendidikan (Pendekatan Kuantitatif, Kualitatif dan $R$ \& D) (Bandung: Alfabeta, 2013), 75, 86

${ }^{10}$ Umul Hidayati, "Pendidikan Holistik Integratif di Raudlatul Athfal," EDUKASI: Jurnal Penelitian Pendidikan Agama dan Keagamaan 15, 2 (2017): 245
} 
olahan data yang peneliti lakukan menunjukkan bahwa kegiatan pemeriksaan kesehatan umum, pemeriksaan kesehatan gigi dan pemeriksaan DDTK sudah terlaksana dengan baik, sedangkan rujukan ke Puskesmas belum terlaksana.

\section{b. Gizi}

Program holistik integratif di bidang gizi meliputi kegiatan pemberian makanan tambahan dan pemberian susu. Kegiatan ini didampingi oleh orang tua murid dan guru kelas dengan pembiayaan oleh orang tua dan PT. Mirota Ksm. Inc. Berdasarkan hasil olahan data yang peneliti lakukan menunjukkan bahwa kegiatan pemberian makanan tambahan dan pemberian susu sudah terlaksana dengan baik di setiap hari Sabtu.

c. Rangsangan pendidikan

Program holistik integratif di bidang rangsangan pendidikan meliputi kegiatan field trip ke PT. Museum Dirgantara Mandala dan pengenalan lingkungan sekolah. Kegiatan field trip ke PT. Museum Dirgantara Mandala dilaksanakan di semester I yang didampingi oleh Kepala TK dan guru dengan pembiayaan dari sekolah. Sementara itu, kegiatan pengenalan lingkungan sekolah dilaksanakan setiap hari Sabtu yang didampingi oleh guru kelas dengan pembiayaan dari sekolah. Berdasarkan hasil olahan data yang peneliti lakukan menunjukkan bahwa kegiatan field trip ke PT. Museum Dirgantara Mandala dan pengenalan lingkungan sekolah sudah terlaksana dengan baik.

d. Pengasuhan

Program holistik integratif di bidang pengasuhan meliputi kegiatan penyambutan, pembiasaan dan penjemputan. Kegiatan ini dilakukan setiap hari oleh guru kelas dengan pembiayaan dari sekolah. Berdasarkan hasil olahan data yang peneliti lakukan menunjukkan bahwa kegiatan penyambutan, pembiasaan dan penjemputan sudah terlaksana dengan baik di setiap hari.

e. Perlindungan

Program holistik integratif di bidang perlindungan meliputi kegiatan parenting perlindungan anak, pemasangan pagar sekolah dan asuransi kesehatan anak. Kegiatan parenting perlindungan anak dilakukan oleh psikolog dengan pembiayaan dari sekolah, kegiatan pemasangan pagar sekolah dilakukan oleh tukang las dengan pembiayaan dari sekolah dan kegiatan asuransi kesehatan dilakukan oleh Asuransi Kesehatan dengan pembiayaan dari orang tua murid. Berdasarkan hasil olahan data yang peneliti lakukan menunjukkan bahwa kegiatan parenting perlindungan anak dan pemasangan pagar 
sekolah sudah terlaksana dengan baik, sedangkan untuk kegiatan asuransi kesehatan anak masih belum terlaksana.

Telaah terhadap berbagai kebijakan holistik integratif yang diterapkan oleh kepala TK Al-Fadlilah menunjukkan bahwa kebijakan tersebut merupakan upaya dalam meningkatkan kredibilitas TK Al-Fadlilah dengan mengembangkan visi dan misi, tujuan serta sasaran yang telah ditetapkan sebelumnya. Berbagai kebijakan tersebut akan terlaksana dengan baik, jika semua pemangku kepentingan di lingkup TK Al-Fadlilah saling bersinergi dengan baik sehingga dapat meningkatkan kredibilitas sekolah di masyarakat.

Selain itu, kebijakan yang telah diterapkan oleh Kepala TK Al-Fadlilah sesuai dengan Peraturan Presiden Nomor 60 Tahun 2013 tentang PAUD HI, sebagai bentuk komitmen pemerintah dalam menjamin terpenuhinya hak tumbuh kembang anak usia dini dalam hal pendidikan, kesehatan, gizi, perawatan, pengasuhan, serta perlindungan dan kesejahteraan anak. Pelaksanaan PAUD HI dilakukan secara simultan, sistematis, menyeluruh, terintegrasi dan berkesinambungan untuk mendukung tumbuh kembang yang optimal demi mewujudkan anak yang sehat, cerdas, dan berkarakter sebagai generasi masa depan yang berkualitas dan kompetitif. ${ }^{11}$

\section{Dampak Kebijakan Holistik Integratif Kepala TK Al-Fadlilah}

Program holistik integratif sebagai sebuah kebijakan kepemimpinan kepala TK Al-Fadlilah, tentu akan membawa banyak dampak terhadap sekolah, baik itu dampak positif maupun dampak negatif. Sejauh mana sebuah kebijakan diimplementasikan, maka sejauh itulah dampaknya akan dirasakan. Proses perkembangan TK Al-Fadlilah akan terjadi karena kebijakan yang diterapkan secara perlahan akan membawa dampak terhadap sekolah. Berdasarkan olahan data yang penulis lakukan menunjukkan bahwa dampak dari program holistik integratif yang diterapkan oleh kepala TK Al-Fadlilah terbagi kepada kedua bentuk, yaitu:

a. Dampak positif

Adapun dampak positif program holistik integratif yang diterapkan oleh kepala TK Al-Fadlilah berdasarkan olahan data yang penulis lakukan, yaitu (1) kesehatan anak-

${ }^{11}$ Direktur Pembinaan PAUD, Petunjuk Teknis Penyelenggaraan PAUD Holistik Integratif di Satuan PAUD (Jakarta: Kemendikbud, 2015), 4 
Remiswal, Arham Junaidi Firman: Penanaman Nilai-nilai KeIslaman...

anak terpantau dengan baik, karena ada kegiatan pemeriksaan kesehatan umum, pemeriksaan kesehatan gigi dan pemeriksaan DDTK terhadap siswa di TK Al-Fadlilah. (2) Ada rujukan ke puskesmas apabila saat pemeriksaan terdapat anak yang sakit dan perlu pengobatan lanjutan, sehingga anak-anak bisa mendapatkan pertolongan kesehatan dengan cepat. (3) Makanan yang dikonsumsi anak terkondisikan dengan baik saat di sekolah, karena ada kegiatan pemberian makanan tambahan dan pemberian susu sudah terlaksana dengan baik disetiap hari Sabtu. (4) Anak-anak lebih mengenal lingkungan di luar sekolah sebagai sarana pembelajaran, karena ada kegiatan field trip ke PT. Museum Dirgantara Mandala dan pengenalan lingkungan sekolah pada setiap semesternya. (5) Anak-anak terbiasa menyapa guru dan teman-teman dengan sapaan yang baik, karena ada kegiatan pengasuhan berupa penyambutan, pembiasaan dan penjemputan anak di sekolah. (6) Anak-anak bermain dengan aman dan ceria di sekolah, karena ada kegiatan parenting perlindungan anak dan pemasangan pagar sekolah sehingga orang tua bisa nyaman melihat anaknya bermain.

\section{b. Dampak negatif}

Adapun dampak negatif program holistik integratif yang diterapkan oleh kepala TK Al-Fadlilah berdasarkan olahan data yang penulis lakukan, yaitu (1) masyarakat terhalangi untuk beribadah di Masjid Al-Fadlilah. Program holistik integratif bidang perlindungan pada kegiatan pagarisasi secara tidak langsung tindakan tersebut berdampak terhadap masyarakat yang ingin beribadah di Masjid Al-Fadlilah. Lokasi TK yang bersebelahan dengan Masjid Al-Fadlilah karena berada dalam satu Yayasan Al-Fadlilah, membawa dampak terhadap kegiatan beribadah masyarakat, hal ini juga didukung oleh semakin sedikitnya jamaah yang melaksanakan shalat berjamaah lima waktu. Pagarisasi yang dilakukan oleh kepala TK Al-Fadlilah, telah menutup jalan setapak yang biasa dilalui oleh masyarakat pejalan kaki untuk beribadah ke masjid. (2) Menjadikan kepala TK sebagai sosok yang memiliki sikap individualis dan tak mau kalah. Tindakan kepala TK Al-Fadlilah yang melakukan pagarisasi sehingga menghalangi kenyamanan masayarakat untuk beribadah, telah menimbulkan kontra dari masyarakat. Masyarakat memandang bahwa sikap tersebut merupakan arogansi individualis yang tidak pantas untuk dilakukan, karena jarak tempuh masyarakat yang biasanya lebih dekat untuk ke masjid sekarang harus memutar jauh untuk bisa ke masjid. Berbagai keluhan yang muncul dari masyarakat terkait kebijakan ini telah disampaikan secara seksama, tetapi belum ada 
tindakan lebih lanjut dari kepala TK untuk mengatasi hal ini, padahal masyarakat telah memberi usul supaya memberi pintu pada jalan setapak yang biasanya dilewati untuk ke masjid.

Telaah terhadap data di atas, mengindikasikan bahwa program holistik integratif yang diterapkan oleh kepala TK Al-Fadlilah telah membawa berbagai dampak positif terhadap perkembangan siswa dan meningkatkan kredibilitas sekolah, namun di samping itu, kebijakan tersebut juga membawa dampak negatif yang tidak bisa dipandang sebelah mata, karena secara tidak langsung berdampak kepada masyarakat dan kepala TK harus jeli dalam mencari penyelesaian terhadap masalah tersebut.

Oleh karena itu, untuk meminimalisir berbagai dampak negatif yang ada, maka dalam pelaksanaan kebijakan holistik integratif harus memperhatikan prinsip-prinsip berikut:

a. Pelayanan yang menyeluruh dan terintegrasi. Satuan PAUD sebagai wadah pemberian layanan pemenuhan kebutuhan pertumbuhan dan perkembangan anak yang mencakup pendidikan, kesehatan, gizi, perawatan, pengasuhan, perlindungan dan kesejahteraan anak oleh berbagai pihak dan pemangku kebijakan;

b. Pelayanan yang berkesinambungan yakni layanan dilakukan pada seluruh layanan PAUD yang dilakukan secara berkelanjutan sejak lahir hingga usia 6 tahun;

c. Pelayanan yang non diskriminasi yakni layanan yang dilaksanakan oleh berbagai pihak dan pemangku kebijakan diberikan kepada seluruh anak yang ada di satuan PAUD secara adil tanpa membeda-bedakan jenis kelamin, status sosial ekonomi, kondisi tumbuh kembang anak (berkebutuhan khusus), suku, agama, ras, antar golongan (SARA);

d. Pelayanan yang tersedia, dapat dijangkau dan terjangkau, serta diterima oleh kelompok masyarakat yakni lokasi layanan PAUD HI diupayakan dekat dengan tempat tinggal masyarakat dan terjangkau dari aspek biaya;

e. Partisipasi masyarakat, yakni melibatkan masyarakat dalam perencanaan, pelaksanaan, pemantauan, dan evaluasi program PAUD HI sehingga rasa memiliki program dari oleh masyarakat menjadi lebih kuat;

f. Berbasis budaya yang konstruktif yakni pemberian layanan pendidikan,kesehatan, gizi, perawatan, pengasuhan, perlindungan, dan kesejahteraan anak dilakukan dengan memanfaatkan potensi lokal dan memperhatikan nilai budaya setempat yang sejalan dengan prinsip lauanan PAUD HI.

g. Tata kelola yang baik yakni pengelolaan program dilakukan secara efektif, efisien, transparan, dan dapat dipertanggungjawabkan. ${ }^{12}$

\footnotetext{
${ }^{12}$ Direktur Pembinaan PAUD, Petunjuk..., 4-5
} 


\section{Faktor yang Mempengaruhi Implementasi Kebijakan Holistik Integratif Kepala TK Al-Fadlilah}

Keberhasilan suatu implementasi kebijakan tergantung kepada berbagai komponen. Kebijakan yang dilaksanakan tidak bisa lepas dari faktor pendukung dan penghambatnya, karena apa yang dilaksanakan oleh kepala TK Al-Fadlilah membutuhkan dorongan dari berbagai elemen baik moril maupun materil. Begitu juga dengan hambatan yang pasti selalu ada dalam kegiatan yang dilakukan. Untuk itu agar program holistik integratif terlaksana dengan baik, maka perlu diperhatikan faktor pendukung dan penghambat dalam implementasi kebijakan tersebut. Berikut adalah faktor pendukung dan penghambat yang dialami dalam implementasi program holistik integratif.

\section{a. Faktor pendukung}

Adapun faktor pendukung implementasi program holistik integratif yang diterapkan oleh kepala TK Al-Fadlilah berdasarkan olahan data yang penulis lakukan, yaitu: (1) kerjasama semua elemen sekolah terbina dengan baik. Kerja sama semua elemen sekolah sangat dibutuhkan dalam menjunjung keberhasilan program di TK AlFadlilah. Dengan kerja sama akan ada proses saling melengkapi, memperbaiki dan menyempurnakan satu dengan yang lain. Peran orang tua, sekolah dan lingkungan masyarakat menjadi prioritas yang tidak bisa dipisahkan. Kematangan pribadi dan lingkungan anak berkembang akan membentuk kesiapan bersekolah pada anak dan hal ini tidak terlepas dari bagaimana pola asuh orang tua terhadap anaknya. Lingkungan pengasuhan orang tua sering dikonseptualisasikan sebagai interaksi antara dua dimensi perilaku orang tua. Dimensi pertama berkenaan dengan hubungan emosional orang tua dengan anak. Dimensi ini mempunyai sebaran mulai dari sikap penerimaan responsif dan orang tua yang memusatkan perhatian kepada kebutuhan dan keinginan sendiri. Dimensi kedua adalah cara- cara orang tua dalam mengontrol perilaku anak-anaknya, meliputi kontrol orang tua yang bersifat membatasi, permisif atau sama sekali tidak ada pembatasan perilaku anak. ${ }^{13}$ Orang tua sebagai penanggung jawab utama pertumbuhan dan perkembangan anak. Keluarga menjadi media yang sangat kuat dan menjadi filter segala apa yang ada, baik internal maupun eksternal. Oleh karena itu kerja sama semua

${ }^{13}$ Anita Chandra Dewi, "Desain Pengembangan Anak Usia Dini Holistik Integratif PAUD Non Formal”, dalam Jurnal Penelitian PAUDIA 2, 1 (2013): 107 
elemen sangat dibutuhkan guna terbina anak yang baik. (2) Pembiayaan dilakukan secara mandiri bekerja sama dengan orang tua murid dan sponsor. Ketersediaan dana merupakan salah satu syarat untuk dapat dilakukanya berbagai kegiatan. Dana merupakan salah satu penentu keberhasilan suatu kegiatan, tanpa di dukung dana suatu kegiatan tidak dapat berjalan dengan lancar bahkan mungkin tidak dapat berjalan sama sekali. Di Tk AlFadlilah untuk pembiayaan dilakukan secara mandiri bekerja sama dengan orang tua dan sponsor. (3) Lingkungan sekitar sekolah sangat kondusif untuk kegiatan anak-anak. Salah satu aspek penting keberhasilan dalam proses pembelajaran yang dilakukan oleh pembelajar/guru adalah penciptaan kondisi pembelajaran yang efektif. Kondisi pembelajara yang efektif disini kondisi yang benar-benar kondusif, kondisi yang benarbenar sesuai dan mendukung kelancaran serta kelangsungan proses pembelajaran serta lingkungan sekitar sekolah sangat sangat kondusif untuk kegiatan anak. Dengan demikian lingkungan belajar merupakan situasi yang menyangkut lingkungan fisik maupun yang menyangkut lingkungan sosial. Lingkungan belajar dapat diciptakan sedemikian rupa, sehingga mampu memfasilitasi peserta didik untuk melaksanakan kegiatan belajar mengajaar dengan nyaman. (4) Sarana dan prasarana sekolah yang ada saat ini mendukung ketercapaian program sekolah tetapi untuk kegiatan lebih lanjut belum mendukung. Sarana dan prasarana pendidikan, khususnya lahan, bangunan dan perlengkapan sekolah seyogyanya menggambarkan program pendidikan yang berlaku, sehingga dengan adanya kesesuaian itu memungkinkan fasilitas yang ada benar-benar menjunjung jalanya pendidikan. Agar program pendidikan bisa tercapai dengan baik maka sarana pra-sarana sangat dibutuhkan di sekolahan.

a. Faktor penghambat

Adapun faktor penghambat implementasi program holistik integratif yang diterapkan oleh kepala TK Al-Fadlilah berdasarkan olahan data yang penulis lakukan, yaitu: (1) sinergitas guru dengan orang tua yang masih belum terjalin dengan baik. Tidak semua orang tua wali peserta didik memahami program yang dijalankan oleh sekolah hal ini akan menghamabat terwujudnya pendidikan yang multikultural. (2) Faktor sarana dan prasarana yang ada masih belum mendukung untuk pengembangan kebijakan sekolah lebih lanjut. (3) Faktor dana yang masih terbatas merupakan hal yang utama dalam mengimplementasikan setiap kebijakan, karena setiap kebijakan yang akan diimplementasikan membutuhkan biaya. (4) Masih minimnya SDM yang berkualitas 
dalam mendukung setiap kebijakan yang ingin diimplementasikan oleh kepala TK AlFadlilah.

Telaah terhadap data di atas, mengindikasikan bahwa jika program holistik integratif di TK Al-Fadlilah ingin terlaksana secara optimal, maka kepala sekolah harus mampu memanfaatkan setiap kelebihan yang dapat mendukung implementasi setiap kebijakan dan meminimalisir faktor-faktor yang dapat menghambat terlaksananya kebijakan yang diterapkan.

\section{Nilai-nilai KeIslaman yang Ditanamkan Melalui Kebijakan Holistik Integratif}

Penanaman nilai-nilai Islam adalah segala usaha memelihara dan mengembangkan fitrah manusia serta sumber daya insani yang ada padanya menuju terbentuknya manusia yang seutuhnya (insan kamil) sesuai dengan norma Islam. ${ }^{14}$ Dalam Islam sendiri terdapat bermacam-macam nilai-nilai agama Islam. Pokok-pokok nilai-nilai Islam yang harus ditanamkan pada anak yaitu aqidah, ibadah dan akhlak. ${ }^{15}$

Hal ini sesuai dengan penanaman nilai-nilai keislaman di TK Al-Fadlilah dapat dikelompokkan menjadi tiga komponen utama, yaitu: akidah (Iman), ibadah (Islam) dan akhlak (Ihsan). Penanaman nilai-nilai Islam sejak dini menjadi kunci utama dalam membentuk karakter positif anak dan akan menjadi pondasi kepribadaian yang kuat dalam perkembangan selanjutnya. Pendidikan karakter harus diberikan kepada anak sejak dini karena usia dini merupakan masa kritis pembentukan karakter seseorang. Kegagalan penanaman karakter pada seseorang sejak usia dini, akan membentuk pribadi yang bermasalah di masa dewasa kelak. ${ }^{16}$

Untuk lebih jelasnya, berikut adalah hasil analisis yang telah dilakukan terhadap penanaman nilai-nilai keIslaman melalui kebijakan holistik integratif di TK Al-Fadlilah.

a. Akidah (Iman)

Nilai-nilai keimanan telah ditanamkan kepada siswa di TK Al-Fadlilah Sambilegi Kidul Yogyakarta dengan menggunakan rangkaian kegiatan yang sederhana. Setiap

\footnotetext{
${ }^{14}$ Abu Ahmadi, Dasar-Dasar Pendidikan Agama Islam untuk Perguruan Tinggi (Jakarta: Bumi Aksara, 2008), 20

${ }^{15}$ Ajat Sudrajat, Din Al-Islam (Pendidikan Agama Islam di Perguruan Tinggi) (Yogyakarta: UNY Press, 2008), 50

${ }^{16}$ Hendro Widodo, "Pendidikan Karakterk Holistik Integratif di PAUD Terpadu 'Aisyiyah Nur'aini Ngampilan Yogyakarta,” Al-Athfal: Jurnal Pendidikan Anak 3, 2 (2017): 137
} 
proses pembelajaran, baik di awal atau di akhir kegiatan, guru TK selalu memasukkan nilai-nilai keimanan kepada siswa, misalnya sebelum kegiatan belajar-mengajar dimulai para guru di TK Al-Fadlilah membimbing para murid membaca iqra' satu persatu. Setelah kegiatan membaca iqra' selesai, lalu dilanjutkan dengan doa bersama sebelum belajar, ini sesuai dengan perkataan Nabi Muhammad, bahwa sebelum melakukan segala aktivitas lebih baik membaca do'a terlebih dahulu dan aktifitas ini sesuai dengan hadis Nabi SAW.

b. Ibadah (Islam)

Nilai-nilai ibadah telah ditanamkan oleh guru kepada siswa dengan mengajarkan tata cara dan praktek shalat wajib, mempraktekkan shalat dhuha satu kali seminggu pada hari sabtu, dzikir dan do'a, cara berwudhu atau melatih berpuasa di bulan Ramadhan, belajar berzakat fitrah, dan belajar manasik haji. Kegiatan-kegiatan ini dilakukan dengan tujuan untuk mendidik siswa di usia dini agar terbiasa dalam melaksanakan berbagai ibadah yang dapat meningkatkan kualitas keimanannya kepada Allah, sehingga kelak ketika ia dewasa, ia tidak pernah lupa untuk beribadah kepada Allah.

c. Akhlak (Ihsan)

Nilai-nilai akhlak karimah juga telah ditanamkan oleh guru kepada siswa di TK Al-Fadlilah dengan mengajarkan sopan santun terhadap guru, orang tua, orang yang lebih tua, makan makanan bergizi bersama, melakukan pengecekan kesehatan kepada siswa yang didampingi oleh pakar ahli kesehatan, belajar bersosialisasi secara baik dengan teman-teman, membiasakan mengucapkan terima kasih atas kebaikan dan jasa orang lain, meminta maaf bila melakukan kesalahan, menjaga kebersihan dan lain-lain.

Jadi, dapat dipahami bahwa kegiatan penanaman nilai-nilai Islam merupakan usaha yang dilakukan secara sadar, terencana dan dapat dipertanggungjawabkan untuk memelihara, melatih, membimbing, mengarahkan dan meningkatkan nilai-nilai Islam yang saling berkaitan satu sama lain dan tidak bisa dipisahkan, yaitu aqidah, ibadah dan akhlak.

\section{Kesimpulan}

Kebijakan kepala sekolah termasuk kepala TK Al-Fadlilah pada dasarnya adalah proses berfikir sistematis dan analitis untuk mengembangkan program-program kebijakan dalam rangka pencapaian tujuan instutisional. Adapun kebijakan kepala TK 
Remiswal, Arham Junaidi Firman: Penanaman Nilai-nilai KeIslaman...

dalam program holistik integratif, yaitu: bidang kesehatan, bidang gizi, bidang rangsangan pendidikan, bidang pengasuhan dan bidang perlindungan. Program holistik integratif sebagai sebuah kebijakan kepemimpinan kepala TK Al-Fadlilah, tentu akan membawa banyak dampak terhadap sekolah, baik itu dampak positif maupun dampak negatif. Sejauh mana sebuah kebijakan diimplementasikan, maka sejauh itulah dampaknya akan dirasakan. Proses perkembangan TK Al-Fadlilah akan terjadi karena kebijakan yang ditarpkan secara perlahan akan membawa dampak terhadap sekolah.

Keberhasilan suatu implementasi kebijakan tergantung kepada berbagai komponen. Kebijakan yang dilaksanakan tidak bisa lepas dari faktor pendukung dan penghambatnya, karena apa yang dilaksanakan oleh kepala TK Al-Fadlilah membutuhkan dorongan dari berbagai elemen baik moril maupun materil. Begitu juga dengan hambatan yang pasti selalu ada dalam kegiatan yang dilakukan. Untuk itu agar program holistik integratif terlaksana dengan baik, maka perlu diperhatikan faktor pendukung dan penghambat dalam implementasi kebijakan tersebut.

Sementara itu, nilai-nilai keIslaman yang ditanamkan kepada siswa di TK AlFadlilah dapat dikelompokkan menjadi tiga komponen utama, yaitu: pertama, akidah (Iman) dengan mengawali dan mengakhiri kegiatan proses pembelajaran melalui do'a. Kedua, ibadah (Islam) dengan mengajarkan tata cara dan praktek shalat wajib, mempraktekkan shalat dhuha satu kali seminggu pada hari sabtu, dzikir dan do'a, cara berwudhu atau melatih berpuasa di bulan Ramadhan, belajar berzakat fitrah, dan belajar manasik haji. Ketiga akhlak (Ihsan) dengan mengajarkan sopan santun terhadap guru, orang tua, orang yang lebih tua, makan makanan bergizi bersama, melakukan pengecekan kesehatan kepada siswa yang didampingi oleh pakar ahli kesehatan, belajar bersosialisasi secara baik dengan teman-teman, membiasakan mengucapkan terima kasih atas kebaikan dan jasa orang lain, meminta maaf bila melakukan kesalahan, menjaga kebersihan dan lain-lain.

\section{E. Daftar Pustaka}

Ahmadi, Abu. Dasar-Dasar Pendidikan Agama Islam untuk Perguruan Tinggi. Jakarta: Bumi Aksara, 2008.

Arikunto, Suharsimi. Dasar-dasar Evaluasi Pendidikan. Jakarta: Aneka Cipta, 2009.

Dewi, Anita Chandra. "Desain Pengembangan Anak Usia Dini Holistik Integratif PAUD Non Formal." Jurnal Penelitian PAUDIA 2, 1 (2013). 
Direktur Pembinaan PAUD. Petunjuk Teknis Penyelenggaraan PAUD Holistik Integratif di Satuan PAUD. Jakarta: Kemendikbud, 2015.

Hidayati, Umul. "Pendidikan Holistik Integratif di Raudlatul Athfal." EDUKASI: Jurnal Penelitian Pendidikan Agama dan Keagamaan 15, 2 (2017).

Mulyasa, E. Menjadi Kepala Sekolah Profesional. Bandung: PT Remaja Rosdakarya, 2007.

Prabowo, Sugeng Listyo. Manajemen Pengembangan Mutu Sekolah/Madrasah. Malang: Uin-Malang Press, 2008.

Setyaningsih, Rini \& Subiyantoro. "Kebijakan Internalisasi Nilai-nilai Islam dalam Pembentukan Kultur Religius Mahasiswa." Edukasia: Jurnal Penelitian Pendidikan Islam 12, 1 (2017).

Suderadjat, Hari. Manajemen Peningkatan Mutu Berbasis Sekolah. Bandung: Cipta Cekas Grafika, 2005.

Sudrajat, Ajat. Din Al-Islam (Pendidikan Agama Islam di Perguruan Tinggi). Yogyakarta: UNY Press, 2008.

Sugiyono. Metode Penelitian Pendidikan (Pendekatan Kuantitatif, Kualitatif dan $R \&$ D). Bandung: Alfabeta, 2013.

Sukmadinata, Nana Syaodih. Metode Penelitian Pendidikan. Bandung: Remaja Rosda Karya, 2005.

Wahjosumidjo. Kepemimpinan Kepala Sekolah. Jakarta: PT Raja Grafindo Persada, 2007.

Widodo, Hendro. "Pendidikan Karakterk Holistik Integratif di PAUD Terpadu 'Aisyiyah Nur'aini Ngampilan Yogyakarta.” Al-Athfal: Jurnal Pendidikan Anak 3, 2 (2017).

Yustiani. "Penanaman Nilai-nilai Karakter Bangsa Melalui Mata Pelajaran Pendidikan Agama Islam di SMA Negeri." Analisa Journal of Social and Religion 22, 01 (2015). 